\title{
NOTCH4 gene polymorphisms as potential risk factors for brain arteriovenous malformation development and hemorrhagic presentation
}

\author{
Daniel Delev, MD, ${ }^{1}$ Anna Pavlova, MD, PhD, ${ }^{2}$ Alexander Grote, MD, ${ }^{1}$ Azize Boström, MD, ${ }^{1}$ \\ Anke Höllig, MD, ${ }^{3}$ Johannes Schramm, MD, ${ }^{1}$ Rolf Fimmers, MD, ${ }^{4}$ Johannes Oldenburg, MD, ${ }^{2}$ and \\ Matthias Simon, MD1
}

\begin{abstract}
${ }^{1}$ Department of Neurosurgery, ${ }^{2}$ Institute for Experimental Haematology and Transfusion Medicine, and ${ }^{4}$ Institute for Medical Biometry, Informatics and Epidemiology, University of Bonn, University Medical Center, Bonn; and ${ }^{3}$ Department of Neurosurgery, University Hospital, RWTH Aachen University, Aachen, Germany
\end{abstract}

\begin{abstract}
OBJECTIVE Arteriovenous malformations (AVMs) of the brain are a frequent and important cause of intracranial hemorrhage in young adults. Little is known about the molecular-genetic pathomechanisms underlying AVM development. Genes of the NOTCH family control the normal development of vessels and proper arteriovenous specification. Transgenic mice with constitutive expression of active NOTCH4 frequently develop AVMs. Here, the authors report a genetic association study investigating possible associations between NOTCH4 gene polymorphisms and formation and clinical presentation of AVMs.
\end{abstract}

METHODS After PCR amplification and direct DNA sequencing or restriction digests, 10 single-nucleotide polymorphisms (SNPs) of the NOTCH4 gene were used for genotyping 153 AVM patients and 192 healthy controls (i.e., blood donors). Pertinent clinical data were available for 129 patients. Uni- and multivariate single-marker and explorative haplotype analyses were performed to identify potential genetic risk factors for AVM development and for hemorrhagic or epileptic presentation.

RESULTS Eleven calculated haplotypes consisting of 3-4 SNPs (most of which were located in the epidermal growth factor-like domain of the NOTCH4 gene) were observed significantly more often among AVM patients than among controls. Univariate analysis indicated that rs443198_TT and rs915895_AA genotypes both were significantly associated with hemorrhage and that an rs1109771_GG genotype was associated with epilepsy. The association between rs443198_TT and AVM bleeding remained significant in the multivariate regression analysis.

CONCLUSIONS The authors' results suggest NOTCH4 SNPs as possible genetic risk factors for the development and clinical presentation of AVMs and a role of NOTCH4 in the pathogenesis of this disease.

https://thejns.org/doi/abs/10.3171/2016.3.JNS151731

KEY WORDS brain arteriovenous malformation; AVM; NOTCH4; single-nucleotide polymorphism; association study; vascular disorders

$\mathrm{A}$ RTERIOVENOUS malformations (AVMs) of the brain are vascular lesions that shunt arterial blood directly into a low-resistance system of draining veins without an intervening normal capillary bed. The prevalence of AVMs ranges from 15 to 18 per 100,000 adults, ${ }^{2}$ with an approximate detection rate of 1 per 100,000 adults per year, ${ }^{6}$ which classifies these vascular malformations as rare diseases. The most common presentation of AVMs is intracerebral hemorrhage, which typically occurs in pa- tients 20-40 years of age and affects approximately 50\% of individuals with AVM. ${ }^{10}$ Moreover, $25 \%-40 \%$ of these patients present with epilepsy. ${ }^{33}$ The risk for an intracerebral hemorrhage varies widely. Rates ranging from $0.9 \%$ in superficial lesions without a history of previous bleeding to 34\% in deep-seated ruptured AVMs have been reported. ${ }^{39}$ Treatment modalities include microsurgery, radiosurgery, and endovascular embolization, all of which carry sometimes substantial morbidity risks. ${ }^{40}$

ABBREVIATIONS AVM = arteriovenous malformation; EGF = epidermal growth factor; SNP = single-nucleotide polymorphism.

SUBMITTED July 26, 2015. ACCEPTED March 9, 2016.

INCLUDE WHEN CITING Published online May 27, 2016; DOI: 10.3171/2016.3.JNS151731. 
The etiology of AVMs is still poorly understood. Some data have suggested a role for a genetic component in the development of AVM. ${ }^{18,19}$ Of note, AVMs are a hallmark of hereditary hemorrhagic telangiectasia. This condition is caused by mutations in the ENG and ACVRL1 genes and characterized by hereditary AVMs involving different organ systems, including the CNS. ${ }^{32}$ In addition, several case-control studies have found associations of singlenucleotide polymorphisms (SNPs) in various candidate genes with susceptibility to AVMs, the risk for hemorrhage, or both. ${ }^{16,17,23,28,36,41}$

NOTCH4 is a member of the NOTCH gene family. Its members govern cellular differentiation and cell-fate determination and control the normal development of vessels and proper arteriovenous specification. NOTCH receptors and their ligands are expressed in arterial walls but not in those of the venous system, ${ }^{20}$ and this arterial expression is both necessary and sufficient to induce that of ephrin$\mathrm{B} 2$, considered to be a specific marker of arterial differentiation. The NOTCH4 gene is located on chromosome 6p21.32. Its 30 exons (Fig. 1A) encode a 2003-amino-acids-long, single-pass transmembrane protein with ankyrin repeats in the intracellular and epidermal growth factor (EGF) repeats in the extracellular NOTCH4 domain. NOTCH4 binds to 2 different ligands: Delta and Serrate/ Jagged. 9,22 Ligand binding to the extracellular domain results in the proteolytic release of the intracellular domain and its translocation to the cell nucleus, which, in turn, initiates the expression of primary target genes belonging to the HES and HER gene families, which are involved in vascular development and proper arteriovenous differentiation. ${ }^{5,13,37}$

Several studies have already suggested a role for $\mathrm{NOTCH}$ signaling in AVM formation and progression to hemorrhage. Recent work with a mouse model with transgenic expression of constitutively active Notch 4 in endothelial cells has demonstrated that upregulation of Notch4 signaling causes vascular abnormalities very similar to those observed in AVM. ${ }^{25-27}$ Conversely, normalization of the elevated Notch4 levels resulted in decreased AVM vessel size. ${ }^{25}$ In addition, genome-wide expression profiling in peripheral blood revealed differential expression of some genes involved in NOTCH signaling in patients with ruptured and unruptured AVMs compared with healthy controls. ${ }^{42}$ Last, NOTCH4 activation in endothelial and smooth-muscle cells of human AVM was very recently demonstrated by immunohistochemistry. ${ }^{44}$ Taken together, these studies suggest a role for NOTCH4 in the formation and phenotypes of AVMs. This observation prompted us to conduct a case-control study to investigate possible associations of genetic polymorphisms in the NOTCH4 gene with disease susceptibility and relevant clinical features.

The present study investigated whether 10 SNPs in the NOTCH4 gene in 153 AVM patients and 192 controls were potentially associated with AVM formation and other clinical findings. Specific NOTCH4 SNP haplotypes were found to be associated with AVM susceptibility, and several single genetic markers could be linked to hemorrhagic (and epileptic) presentation. These data provide support for a role of the NOTCH4 gene in the formation and progression of AVM. They also suggest that NOTCH4 genetic variants may have potential for use as new clinical biomarkers.

\section{Methods \\ Study Cohort}

In total, this study included 153 white patients with AVMs, $50 \%$ of whom were male. The median age at treatment was $39 \pm 15.5$ years (mean 41 , range 9-70 years). All patients had undergone diagnostic digital subtraction angiography. ${ }^{34}$ In 108 patients who underwent surgery, the diagnosis of AVM was confirmed histologically. Clinical and angiographic data were available for 129 patients (Table 1).

The control group consisted of 192 white healthy blood donors (96 men and 96 women), with a median age of $27 \pm$ 5.5 years (mean 25, range 18-60 years). Before any blood donation, all candidate donors underwent a thorough clinical examination and were asked to fill out an extensive questionnaire about their own and family medical histories. In case of any medical conditions or signs and symptoms pointing to any significant disease (including recurrent headaches or epilepsy), cardiovascular risk factors, or hereditary diseases in either the individual or her or his family, the candidate donor was excluded from blood donation.

The study was approved by the ethics committee of the University of Bonn Medical Center. Informed consent was obtained from all patients and controls according to the Declaration of Helsinki.

\section{Selection and Genotyping of NOTCH4 Gene SNPs}

Ten (2 exonic and 8 intronic) SNPs (rs434841 [A/G], rs3134931 [A/G],rs443198 [C/T],rs915895 [A/G],rs715299 [A/C], rs415929 [A/G], rs1109771 [A/G], rs3134798 [C/T], rs2071286 [A/G], and rs2071279 [G/T]) of the NOTCH4 gene were selected from the HapMap project data (http:// hapmap.org). We applied the SNPs Tagger algorithm ${ }^{11}$ implemented in Haploview (dbSNP b126 on the National Center for Biotechnology Information b36 assembly), ${ }^{4}$ with the following characteristics: minor allele frequency $<2 \%$ in the white CEU population, pairwise selection, $\mathrm{r}^{2}$ cutoff $>0.8$, and maximum DNA segment size of $250 \mathrm{bp}$.

High-molecular-weight genomic DNA was isolated from leukocytes with a salting-out procedure. ${ }^{24}$ All 10 polymorphisms were analyzed after PCR amplification, followed by restriction-enzyme digest analysis for 2 SNPs and direct sequencing of both DNA strands with the BigDye Terminator Cycle Sequencing V1.1 Ready Reaction kit and an automated ABI-3100 DNA sequencer (Applied Biosystems) for the remaining 8 SNPs. Primers were designed with the Primer3 software version 0.4.0 (Whitehead Institute for Biomedical Research). Details on the primers, ${ }^{38}$ restriction enzymes, and PCR conditions used are available on request.

\section{Haplotype Analysis}

Recent work has suggested that a multimarker (haplotype) analysis may improve genotyping efficiency and refine the association signal. ${ }^{11}$ We therefore performed an explorative haplotype study and calculated all possible haplotypes consisting of up to 4 SNPs. This analysis re- 

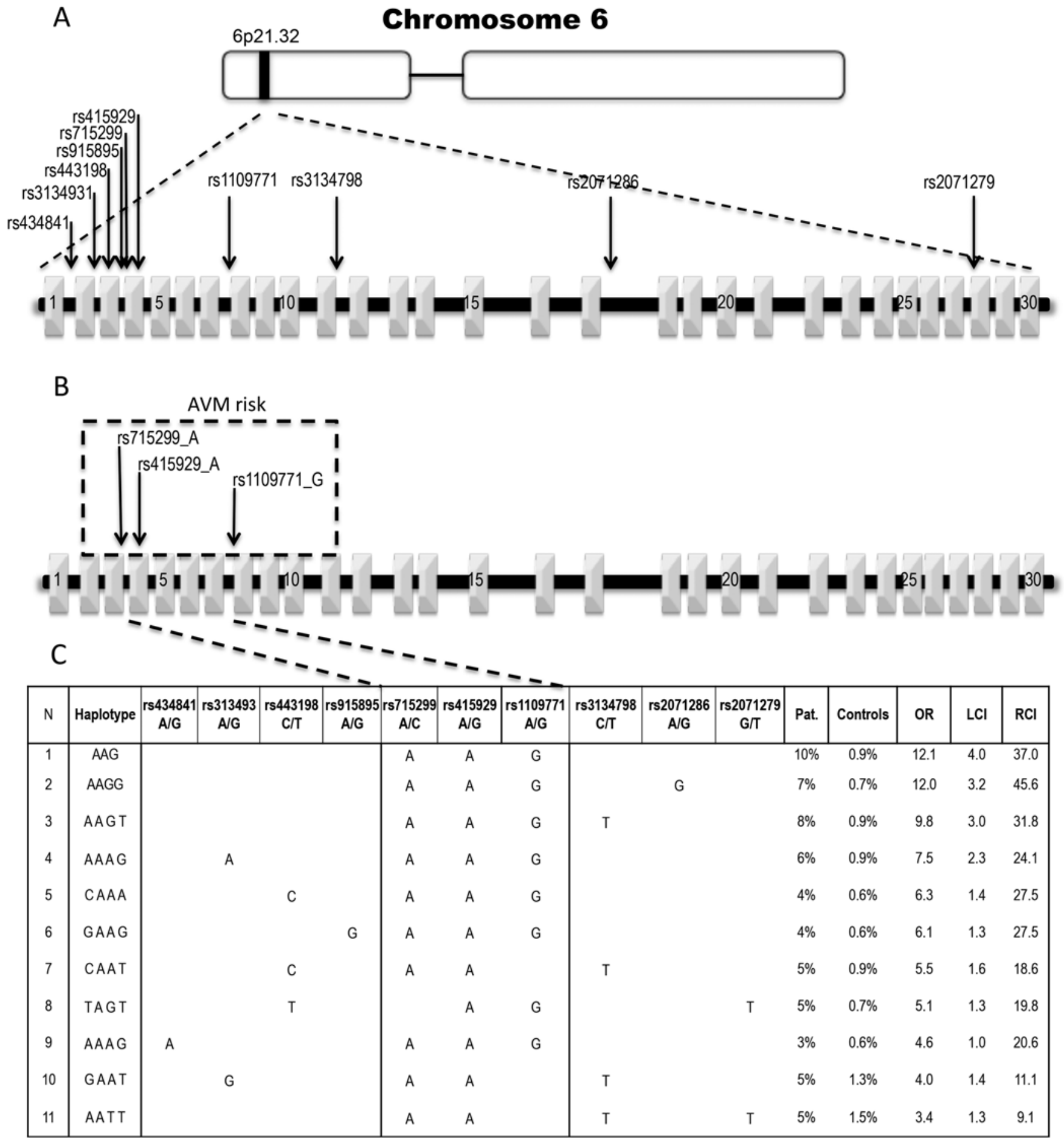

FIG. 1. A: The location of the NOTCH4 gene on Chromosome 6 and the distribution of all the SNPs investigated in the present study throughout the gene. The rectangles (1-30) represent the gene exons. B: The 3 SNPs that were present in all haplotypes associated with increased susceptibility to AVM. Interestingly, they are located in a part of the gene coding for the $\mathrm{Ca}^{2+}-$ binding region of the EGF-like domain of the NOTCH4 protein (not shown). C: Calculated haplotype frequencies of the NOTCH4 SNPS that were associated with increased AVM susceptibility (uncorrected $\mathrm{p} \leq 1 \times 10^{-15}$ ). $\mathrm{LCl}=$ left $95 \% \mathrm{Cl}$; Pat. $=$ patients; $\mathrm{RCl}=$ right $95 \% \mathrm{Cl}$.

sulted in calculated haplotype frequencies of $1 \%$ in some cases. This low haplotype frequency, along with the limited number of patients and controls in this study, precluded further analysis of more complex haplotypes.

\section{Genotype-Phenotype Correlations}

Because the data from the association study suggested a link between NOTCH4 gene variants and AVM biology, we also looked for possible correlations between 
TABLE 1. Patient characteristics

\begin{tabular}{|c|c|}
\hline Characteristic & No. of Patients $(n=129)$ \\
\hline Mean age in yrs (median \pm SD [range]) & $41(39 \pm 15.5[9-70])$ \\
\hline $\mathrm{M} / \mathrm{F}$ ratio & $65: 64$ \\
\hline \multicolumn{2}{|l|}{ Epilepsy } \\
\hline Present & 56 \\
\hline Absent & 72 \\
\hline Not determined & 1 \\
\hline \multicolumn{2}{|l|}{ Hemorrhage } \\
\hline Present & 64 \\
\hline Absent & 65 \\
\hline \multicolumn{2}{|l|}{ AVM-associated aneurysm } \\
\hline Present & 17 \\
\hline Absent & 112 \\
\hline \multicolumn{2}{|l|}{ Deep drainage } \\
\hline Present & 49 \\
\hline Absent & 80 \\
\hline \multicolumn{2}{|l|}{ Location } \\
\hline Superficial & 74 \\
\hline Deep & 31 \\
\hline Not determined & 24 \\
\hline Supratentorial & 116 \\
\hline Infratentorial & 13 \\
\hline \multicolumn{2}{|l|}{ AVM size } \\
\hline$\geq 3 \mathrm{~cm}$ & 58 \\
\hline$<3 \mathrm{~cm}$ & 71 \\
\hline \multicolumn{2}{|l|}{ Spetzler-Martin grade } \\
\hline 1 & 19 \\
\hline II & 59 \\
\hline III & 43 \\
\hline IV & 7 \\
\hline V & 1 \\
\hline \multicolumn{2}{|l|}{ Treatment } \\
\hline Surgery only & 93 \\
\hline Embolization \& surgery & 15 \\
\hline Radiosurgery only & 5 \\
\hline Embolization \& radiosurgery & 16 \\
\hline
\end{tabular}

NOTCH4 SNP genotypes and clinical parameters. Hence, we investigated all SNPs as potential predictors of hemorrhagic presentation or presentation with epilepsy.

\section{Biostatistical Analysis}

Hardy-Weinberg equilibrium and linkage disequilibrium were estimated with Haploview software V4.0. ${ }^{4}$ All investigated SNPs were in Hardy-Weinberg equilibrium among cases and controls. The Cochrane-Armitage trend test was applied to compare genotype frequencies among AVM patients, AVM patient subsets, and healthy controls. Statistical significance of correlations among clinical parameters and of genotype-phenotype correlations was assessed with standard methods, including multivariate logistic regression analyses. All tests were 2 sided, and a $\mathrm{p}$ value $<0.05$ was considered statistically significant. The FAMHAP software V19.0 ${ }^{14}$ was used to calculate and compare haplotype frequencies consisting of up to 4 SNPs in patients versus controls and of up to 3 SNPs in patient subsets.

\section{Results}

\section{Clinical and Angiographic Data}

Relevant clinical and demographic data were retrieved for 129 patients and included the following parameters: clinical presentation (bleeding, epilepsy, or other), maximum AVM diameter, presence or absence of AVM-associated aneurysms or deep venous drainage, and AVM location and Spetzler-Martin grade ${ }^{34}$ (Table 1). Sixty-four $(50 \%)$ patients had a history of AVM bleeding, and symptomatic epilepsy was recorded in $56(43 \%)$ patients. One hundred eight (84\%) patients had surgery for AVM, 15 of whom had undergone AVM embolization before the operation. Five patients underwent only radiosurgery, and 16 patients underwent a combination of radiosurgery and embolization. Nineteen of the patients had Spetzler-Martin Grade I AVMs, 59 Grade II, 43 Grade III, 7 Grade IV, and 1 Grade V.

\section{NOTCH4 SNP Haplotypes Are Associated With Susceptibility to AVMs}

In total, 153 AVM patients and 192 healthy individuals were genotyped for 10 different NOTCH4 SNPs. To determine if any of the NOTCH4 SNPs were associated with susceptibility to the disease, we performed a case-control analysis comparing the SNP genotype distributions in the patient and control groups. No statistically significant correlations were detected, and only a trend for an association was observed for the rs3134798 SNP $(p=0.1)$.

Next, as outlined in Methods, calculated haplotype frequencies were compared between the 2 groups. After Bonferroni correction for multiple testing, this analysis revealed that 11 haplotypes were significantly more common among the AVM patients (uncorrected $\mathrm{p} \leq 1 \times 10^{-}$ ${ }^{15}$ ), suggesting that these haplotypes were associated with greater susceptibility to AVM. Interestingly, the haplotypes did not map randomly to the NOTCH4 gene. Rather, all of them contained at least 2 of 3 SNPs (rs1109771 $[\mathrm{A} / \mathrm{G}], \mathrm{rs} 415929[\mathrm{~A} / \mathrm{G}]$, and rs715299 [A/C]), which were all localized to the region of the gene coding for the $\mathrm{Ca}^{2+}$ binding part of the EGF-like domain of the NOTCH4 protein (Fig. 1B and C).

\section{Genotype-Phenotype Correlations}

Univariate analysis indicated that the homozygous rs443198_TT and rs915895_AA genotypes were statistically significantly associated with a greater risk for hemorrhage than their heterozygous reference genotypes (Table 2). Univariate analysis also revealed that clinical parameters that were significantly correlated with AVM bleeds in the present series included an AVM size of $<3 \mathrm{~cm}$ and no epilepsy at presentation. A multivariate stepwise regression analysis including rs443198_TT, rs915895_AA, AVM size $<3 \mathrm{~cm}$, and no epilepsy at presentation as covariates confirmed rs443198_TT and no epilepsy at pre- 
TABLE 2. Univariate analysis of clinical and genetic factors influencing the risk for AVM hemorrhage

\begin{tabular}{|c|c|c|c|c|c|}
\hline \multirow[b]{2}{*}{ Characteristic } & \multicolumn{2}{|c|}{ No. of Patients (\%) ${ }^{*}$} & \multirow[b]{2}{*}{ OR } & \multirow[b]{2}{*}{$95 \% \mathrm{Cl}$} & \multirow[b]{2}{*}{$\begin{array}{c}p \\
\text { Value }\end{array}$} \\
\hline & Hemorrhage & $\begin{array}{c}\text { No } \\
\text { Hemorrhage }\end{array}$ & & & \\
\hline \multicolumn{6}{|l|}{ Sex } \\
\hline Male & $30(46)$ & $35(54)$ & 0.76 & $0.38-1.51$ & 0.429 \\
\hline Female & $34(53)$ & $30(47)$ & & & \\
\hline $\begin{array}{c}\text { Mean age at } \\
\text { Dx } \pm S D \\
\text { in yrs }\end{array}$ & $39.7 \pm 13.6$ & $41.9 \pm 17.5$ & 1.01 & $0.99-1.03$ & 0.437 \\
\hline \multicolumn{6}{|l|}{ AVM location } \\
\hline $\begin{array}{l}\text { Supraten- } \\
\text { torial }\end{array}$ & $56(48)$ & $60(52)$ & 0.58 & $0.18-1.89$ & 0.369 \\
\hline $\begin{array}{l}\text { Infratento- } \\
\text { rial }\end{array}$ & $8(62)$ & $5(38)$ & & & \\
\hline \multicolumn{6}{|l|}{ Deep location } \\
\hline Yes & $18(58)$ & $13(42)$ & 1.54 & $0.66-3.60$ & 0.316 \\
\hline No & $35(47)$ & $39(53)$ & & & \\
\hline \multicolumn{6}{|l|}{ Aneurysm } \\
\hline Present & $6(35)$ & $11(65)$ & 0.51 & $0.18-1.47$ & 0.211 \\
\hline Absent & $58(52)$ & $54(48)$ & & & \\
\hline \multicolumn{6}{|l|}{$\begin{array}{l}\text { Deep drain- } \\
\quad \text { age }\end{array}$} \\
\hline Present & $25(51)$ & $24(49)$ & 1.10 & $0.54-2.23$ & 0.802 \\
\hline Absent & $39(49)$ & $41(51)$ & & & \\
\hline \multicolumn{6}{|l|}{ Epilepsy } \\
\hline Absent & $46(64)$ & $26(36)$ & 3.73 & $1.78-7.82$ & $0.001 \dagger$ \\
\hline Present & $18(32)$ & $38(68)$ & & & \\
\hline \multicolumn{6}{|l|}{ AVM size } \\
\hline$<3 \mathrm{~cm}$ & $41(58)$ & $30(42)$ & 2.08 & $1.03-4.21$ & $0.042 \dagger$ \\
\hline$\geq 3 \mathrm{~cm}$ & $23(40)$ & $35(60)$ & & & \\
\hline \multicolumn{6}{|l|}{$\begin{array}{l}\text { Spetzler-Mar- } \\
\text { tin grade }\end{array}$} \\
\hline I & $12(63)$ & $7(37)$ & 2.86 & $0.52-15.77$ & 0.178 \\
\hline II & $26(44)$ & $33(56)$ & 1.31 & $0.29-6.01$ & 0.467 \\
\hline III & $23(54)$ & $20(46)$ & 1.92 & $0.41-9.05$ & 0.626 \\
\hline IV or V & $3(38)$ & $5(62)$ & & & \\
\hline \multicolumn{6}{|l|}{ rs_443198 } \\
\hline CC vs TT & $9(75)$ & $3(25)$ & 0.46 & $0.11-1.91$ & 0.096 \\
\hline TT vs CT & $29(58)$ & $21(42)$ & 2.12 & $1.01-4.49$ & $0.010 \dagger$ \\
\hline $\mathrm{CT}$ & $26(39)$ & $40(61)$ & & & \\
\hline \multicolumn{6}{|l|}{ rs_915895 } \\
\hline GG vs $A A$ & $6(75)$ & $2(25)$ & 0.47 & $0.09-2.55$ & 0.996 \\
\hline$A A$ vs $A G$ & $31(58)$ & $22(42)$ & 2.14 & $1.03-1.44$ & $0.022 \dagger$ \\
\hline$A G$ & $27(40)$ & $41(60)$ & & & \\
\hline
\end{tabular}

sentation as independent variables significantly associated with hemorrhage (Table 3).

Statistically significant predictors of epileptic presentation included the rs1109771_GG genotype, AVM size $\geq$
TABLE 3. Multivariate regression analysis of 4 variables significantly associated with hemorrhage in the univariate analysis

\begin{tabular}{lccc}
\hline \multicolumn{1}{c}{ Variable } & OR & $95 \% \mathrm{Cl}$ & $\mathrm{p} \mathrm{Value}$ \\
\hline No epilepsy & 4.65 & $1.83-8.70$ & $0.001^{*}$ \\
\hline AVM size $<3 \mathrm{~cm}$ & $\mathrm{NS}$ & $\mathrm{NS}$ & $>0.05$ \\
\hline rs_443198_TT & 2.11 & $0.95-4.67$ & $0.028^{*}$ \\
\hline rs_915895_AA & $\mathrm{NS}$ & $\mathrm{NS}$ & $>0.05$ \\
\hline NS = not significant. & & & \\
* Statistically significant p value. & &
\end{tabular}

$3 \mathrm{~cm}$, nonhemorrhagic presentation, and supratentorial versus infratentorial location $(\mathrm{p}<0.001)$ (Table 4). When we performed multivariate stepwise regression analysis with rs1109771_GG, AVM size $\geq 3 \mathrm{~cm}$, and presentation as covariates, only nonhemorrhagic presentation remained an independent predictor for epilepsy (Table 5).

Following the same rationale as outlined above for the susceptibility study, we also performed explorative haplotype analyses to look for genotype-phenotype correlations of NOTCH4 haplotypes with clinical presentation. Because of the smaller sample size (129 patients versus a total of 345 cases and controls in the susceptibility study), we restricted this analysis to haplotypes consisting of up to 3 SNPs. Several statistically significant associations were observed, none of which remained significant after correction for multiple testing.

\section{Discussion}

Brain AVMs represent an important cause for neurological impairment due to intracerebral bleeding or sometimes symptomatic epilepsy in young adults. ${ }^{32,33}$ Prevention of AVM hemorrhages (or rehemorrhages) remains the primary goal of AVM treatment, and clinical decision making often consists of balancing the presumed risk of (further) bleeds against the risks of AVM treatment. A better understanding of the biology of the disease could lead to the identification of novel biomarkers for the prediction of the patients' future clinical course (i.e., for hemorrhage prediction) or even ultimately result in the development of new treatment strategies. Studying the genetic factors involved in a certain disease may identify genes and biological mechanisms underlying its pathogenesis. Following this rationale, we and others have investigated genetic polymorphisms of candidate genes for possible associations with susceptibility to AVMs and with specific clinical features of the disease such as hemorrhagic presentation. ${ }^{17,18,23,28,32,35}$

In the present work, we tested whether SNPs in the NOTCH4 gene are potential genetic risk factors for the development of AVMs, AVM bleeds, or AVM-associated epilepsy. Our results suggest a role of the NOTCH4 gene in AVM biology. First, they suggest an association between NOTCH4 gene SNPs and increased susceptibility to AVMs. Second, our results from the multivariate analysis also linked certain NOTCH4 gene variants to key clinical features such as hemorrhage. We note that NOTCH4 is a highly plausible candidate AVM gene. Murphy et al. 
TABLE 4. Univariate analysis of clinical and genetic factors in AVM patients influencing the risk for presenting with epilepsy

\begin{tabular}{|c|c|c|c|c|c|}
\hline \multirow[b]{2}{*}{ Characteristic } & \multicolumn{2}{|c|}{ No. of Patients $(\%)^{*}$} & \multirow[b]{2}{*}{ OR } & \multirow[b]{2}{*}{$95 \% \mathrm{Cl}$} & \multirow[b]{2}{*}{$p$ Value } \\
\hline & Epilepsy & No Epilepsy & & & \\
\hline \multicolumn{6}{|l|}{ Sex } \\
\hline Male & $31(48)$ & $33(52)$ & 1.46 & $0.73-2.96$ & 0.286 \\
\hline Female & $25(39)$ & $39(61)$ & & & \\
\hline $\begin{array}{l}\text { Mean age at } \\
D x \pm S D \text { in } \\
\text { yrs }\end{array}$ & $41.0 \pm 13.6$ & $40.9 \pm 16.9$ & 1.00 & $0.98-1.02$ & 0.986 \\
\hline \multicolumn{6}{|l|}{ Hemorrhage } \\
\hline Absent & $46(64)$ & $26(36)$ & 3.73 & $1.78-7.82$ & $0.001 \dagger$ \\
\hline Present & $18(32)$ & $38(68)$ & & & \\
\hline \multicolumn{6}{|l|}{ Deep location } \\
\hline Present & $9(29)$ & $22(71)$ & 0.42 & $0.17-1.04$ & 0.060 \\
\hline Absent & $36(49)$ & $37(51)$ & & & - \\
\hline \multicolumn{6}{|l|}{ Aneurysm } \\
\hline Present & $9(53)$ & $8(47)$ & 1.53 & $0.55-4.26$ & 0.414 \\
\hline Absent & $47(42)$ & $64(58)$ & & & - \\
\hline \multicolumn{6}{|l|}{ Deep drainage } \\
\hline Present & $25(51)$ & $24(49)$ & 1.61 & $0.78-3.31$ & 0.193 \\
\hline Absent & $31(39)$ & $48(61)$ & & & \\
\hline \multicolumn{6}{|l|}{ AVM location } \\
\hline $\begin{array}{l}\text { Infratento- } \\
\quad \text { rial }\end{array}$ & $0(0.00)$ & $13(100)$ & NA & NA & $<0.001 \dagger$ \\
\hline $\begin{array}{l}\text { Supratento- } \\
\text { rial }\end{array}$ & $56(48)$ & $59(52)$ & & & \\
\hline \multicolumn{6}{|l|}{ AVM size } \\
\hline$<3 \mathrm{~cm}$ & $25(36)$ & $45(64)$ & & & \\
\hline$\geq 3 \mathrm{~cm}$ & $31(53)$ & $27(47)$ & 2.07 & $1.02-4.21$ & $0.045 \dagger$ \\
\hline \multicolumn{6}{|l|}{$\begin{array}{l}\text { Spetzler-Mar- } \\
\text { tin grade }\end{array}$} \\
\hline I & $6(32)$ & $13(68)$ & 0.28 & $0.05-1.56$ & 0.152 \\
\hline II & $24(41)$ & $34(59 \%)$ & 0.42 & $0.09-1.94$ & 0.549 \\
\hline III & $21(48)$ & $22(52)$ & 0.57 & $0.12-2.70$ & 0.717 \\
\hline IV or $\mathrm{V}$ & $5(62)$ & $3(38)$ & & & \\
\hline \multicolumn{6}{|l|}{ rs_1109771 } \\
\hline$A A$ vs $G G$ & $10(37)$ & $17(63)$ & 0.44 & $0.16-1.18$ & 0.364 \\
\hline$G G$ vs $A G$ & $23(58)$ & $17(42)$ & 2.34 & $1.03-5.29$ & $0.034 \dagger$ \\
\hline$A G$ & $22(37)$ & $38(63)$ & & & \\
\hline
\end{tabular}

* Row percentages are shown.

$\dagger$ Statistically significant $p$ value.

have shown that expression of constitutively active Notch 4 leads to the development of AVMs in mice. ${ }^{26,27}$ Moreover, normalizing Notch4 signaling by turning off constitutive expression of the Notch 4 gene in mice reduces AVM vessel size. ${ }^{25}$ Using immunohistochemistry, ZhuGe and colleagues have recently shown upregulation and activation of NOTCH4 in endothelial and smooth-muscle cells in human AVMs. ${ }^{44}$

A number of studies have investigated genetic polymorphisms for possible associations with AVM development; however, many of these investigations have focused on
TABLE 5. Multivariate regression analysis of 3 variables significantly associated with epileptic presentation in the univariate analysis

\begin{tabular}{lccc}
\hline \multicolumn{1}{c}{ Variable } & OR & $95 \% \mathrm{Cl}$ & $\mathrm{p}$ Value \\
\hline Hemorrhage & 0.27 & $0.13-0.56$ & $0.001^{*}$ \\
\hline AVM size $\geq 3 \mathrm{~cm}$ & NS & NS & $>0.05$ \\
\hline rs_1109771_GG & NS & NS & $>0.05$ \\
\hline
\end{tabular}

* Statistically significant $p$ value.

genes with roles in inflammatory pathways. ${ }^{1,8,12,17,28}$ In contrast, genes involved in angiogenesis have so far received surprisingly little attention. ${ }^{30,41}$ Genes with a known role in angiogenesis that have been reported to be associated with AVM formation include ALK $1,{ }^{29,32}$ ANGPTL4, ${ }^{23}$ and $V E G F$ ? Interestingly, the VEGF and ALK1 pathways involved in vascular development interact with the NOTCH pathway. ${ }^{21,31}$ Most recently, Zhang and coworkers proposed an AVM pathogenesis pathway in which NOTCH signaling is located downstream of AVM-causative genes like $A L K 1$ and $V E G F{ }^{43}$

We did not detect statistically significant correlations between single NOTCH4 SNPs and AVM formation, which may be well explained by the relatively small size of our patient cohort. However, it has been shown that haplotype-based tagging can outperform single-marker tests and can help to both increase the association efficiency and refine the association signal. ${ }^{11}$ Therefore, we also investigated whether calculated haplotypes consisting of up to 4 SNPs were possibly associated with AVM. We note that this approach was somewhat exploratory; however, this analysis linked specific haplotypes to an increased risk for developing AVM (Fig. 1B and C). In addition, we did find a single-marker association between the NOTCH4 rs443198_TT SNP genotype and a key clinical feature, that is, presentation with hemorrhage. Of note, in the multivariate regression analysis, rs443198_TT remained a statistically significant predictor of a hemorrhagic presentation. Interestingly, rs443198_TT has not been previously reported to be associated with hemorrhage in other diseases, an observation that points to a possible specific involvement of this NOTCH4 SNP in AVM-associated hemorrhage.

The NOTCH4 SNPs linked to AVM biology in our analyses did not map randomly to the gene, supporting the contention that our results are not chance findings. All of the haplotypes linked to an increased risk for AVM formation contained at least 2 of 3 SNPs (rs715299, rs415929, and rs110977), all of which map to the $\mathrm{Ca}^{2+}$-binding sites of the NOTCH4 EGF-like receptor domain (Fig. 1B and C), which is known to play an important role in receptorligand interactions. Therefore, any genetic or structural variance in this region might have functional consequences. The rs443198 SNP, which is linked to clinical presentation of hemorrhage, maps relatively closely to rs715299 and was also present in several haplotypes associated with AVM formation. rs443198 is located in the coding part of exon 3 and is predicted to result in an (albeit synonymous) amino acid change or in an alternative splice site. ${ }^{15}$ 


\section{Limitation of the Study and Further Investigations}

Our study has significant limitations. First, the small sample size in our study could have led to false-positive associations and confounder effects. Second, our conclusions are based in part on calculated haplotype frequencies. This approach was somewhat exploratory, the results of which may not be as robust as the results of a casecontrolled comparison of SNP genotype distributions. The results of our study suggest but do not provide conclusive evidence for a significant link between NOTCH4 and AVM disease. Nevertheless, we believe that the data presented here, along with previous preclinical investigations in animal models, support a role for NOTCH4 in the formation and presentation of AVM. We propose that validation of our results via a confirmatory analysis of an independent and, if possible, larger AVM patient cohort will be a crucial next step.

\section{Conclusions}

Our results point to a role of the NOTCH4 gene in the formation and progression of AVM. Our data suggest that some NOTCH4 gene SNPs are linked to the risk for developing an AVM and also to AVM clinical parameters such as hemorrhage and epilepsy. We note the limitations of our study, most notably its small sample size, which may allow for differences in the cohort substructure to go undetected, leading to false-positive associations or confounder effects. Nevertheless, we believe that our data clearly warrant follow-up studies and, if possible, confirmation in a larger patient cohort.

\section{References}

1. Achrol AS, Pawlikowska L, McCulloch CE, Poon KYT, Ha C, Zaroff JG, et al: Tumor necrosis factor-alpha-238G $>$ A promoter polymorphism is associated with increased risk of new hemorrhage in the natural course of patients with brain arteriovenous malformations. Stroke 37:231-234, 2006

2. Al-Shahi R, Fang JSY, Lewis SC, Warlow CP: Prevalence of adults with brain arteriovenous malformations: a community based study in Scotland using capture-recapture analysis. J Neurol Neurosurg Psychiatry 73:547-551, 2002

3. Atkinson RP, Awad IA, Batjer HH, Dowd CF, Furlan A, Giannotta SL, et al: Reporting terminology for brain arteriovenous malformation clinical and radiographic features for use in clinical trials. Stroke 32:1430-1442, 2001

4. Barrett JC, Fry B, Maller J, Daly MJ: Haploview: analysis and visualization of LD and haplotype maps. Bioinformatics 21:263-265, 2005

5. Boucher J, Gridley T, Liaw L: Molecular pathways of notch signaling in vascular smooth muscle cells. Front Physiol 3:81, 2012

6. Brown RD Jr, Wiebers DO, Torner JC, O'Fallon WM: Frequency of intracranial hemorrhage as a presenting symptom and subtype analysis: a population-based study of intracranial vascular malformations in Olmsted Country, Minnesota. J Neurosurg 85:29-32, 1996

7. Chen H, Gu Y, Wu W, Chen D, Li P, Fan W, et al: Polymorphisms of the vascular endothelial growth factor A gene and susceptibility to sporadic brain arteriovenous malformation in a Chinese population. J Clin Neurosci 18:549-553, 2011

8. Chen Y, Pawlikowska L, Yao JS, Shen F, Zhai W, Achrol AS, et al: Interleukin-6 involvement in brain arteriovenous malformations. Ann Neurol 59:72-80, 2006
9. Chillakuri CR, Sheppard D, Lea SM, Handford PA: Notch receptor-ligand binding and activation: insights from molecular studies. Semin Cell Dev Biol 23:421-428, 2012

10. Choi JH, Mohr JP: Brain arteriovenous malformations in adults. Lancet Neurol 4:299-308, 2005

11. de Bakker PIW, Yelensky R, Pe'er I, Gabriel SB, Daly MJ, Altshuler D: Efficiency and power in genetic association studies. Nat Genet 37:1217-1223, 2005

12. Fontanella M, Rubino E, Crobeddu E, Gallone S, Gentile S, Garbossa D, et al: Brain arteriovenous malformations are associated with interleukin-1 cluster gene polymorphisms. Neurosurgery 70:12-17, 2012

13. Gridley T: Notch signaling in vascular development and physiology. Development 134:2709-2718, 2007

14. Herold C, Becker T: Genetic association analysis with FAMHAP: a major program update. Bioinformatics 25:134-136, 2009

15. Keren H, Lev-Maor G, Ast G: Alternative splicing and evolution: diversification, exon definition and function. Nat Rev Genet 11:345-355, 2010

16. Kim H, Hysi PG, Pawlikowska L, Choudhry S, González Burchard E, Kwok PY, et al: Population stratification in a case-control study of brain arteriovenous malformation in Latinos. Neuroepidemiology 31:224-228, 2008

17. Kim H, Hysi PG, Pawlikowska L, Poon A, Burchard EG, Zaroff JG, et al: Common variants in interleukin-1-Beta gene are associated with intracranial hemorrhage and susceptibility to brain arteriovenous malformation. Cerebrovasc Dis 27:176-182, 2009

18. Kim H, Marchuk DA, Pawlikowska L, Chen Y, Su H, Yang GY, et al: Genetic considerations relevant to intracranial hemorrhage and brain arteriovenous malformations. Acta Neurochir Suppl 105:199-206, 2008

19. Kim H, Su H, Weinsheimer S, Pawlikowska L, Young WL: Brain arteriovenous malformation pathogenesis: a responseto-injury paradigm. Acta Neurochir Suppl 111:83-92, 2011

20. Kume T: Specification of arterial, venous, and lymphatic endothelial cells during embryonic development. Histol Histopathol 25:637-646, 2010

21. Larrivée B, Prahst C, Gordon E, del Toro R, Mathivet T, Duarte A, et al: ALK1 signaling inhibits angiogenesis by cooperating with the Notch pathway. Dev Cell 22:489-500, 2012

22. Li L, Huang GM, Banta AB, Deng Y, Smith T, Dong P, et al: Cloning, characterization, and the complete 56.8-kilobase DNA sequence of the human NOTCH4 gene. Genomics 51:45-58, 1998

23. Mikhak B, Weinsheimer S, Pawlikowska L, Poon A, Kwok PY, Lawton MT, et al: Angiopoietin-like 4 (ANGPTL4) gene polymorphisms and risk of brain arteriovenous malformations. Cerebrovasc Dis 31:338-345, 2011

24. Miller SA, Dykes DD, Polesky HF: A simple salting out procedure for extracting DNA from human nucleated cells. Nucleic Acids Res 16:1215, 1988

25. Murphy PA, Kim TN, Lu G, Bollen AW, Schaffer CB, Wang RA: Notch4 normalization reduces blood vessel size in arteriovenous malformations. Sci Transl Med 4:117ra8, 2012

26. Murphy PA, Lam MTY, Wu X, Kim TN, Vartanian SM, Bollen AW, et al: Endothelial Notch4 signaling induces hallmarks of brain arteriovenous malformations in mice. Proc Natl Acad Sci U S A 105:10901-10906, 2008

27. Murphy PA, Lu G, Shiah S, Bollen AW, Wang RA: Endothelial Notch signaling is upregulated in human brain arteriovenous malformations and a mouse model of the disease. Lab Invest 89:971-982, 2009

28. Pawlikowska L, Poon KYT, Achrol AS, McCulloch CE, Ha C, Lum K, et al: Apolipoprotein E epsilon 2 is associated with new hemorrhage risk in brain arteriovenous malformations. Neurosurgery 58:838-843, 2006

29. Pawlikowska L, Tran MN, Achrol AS, Ha C, Burchard E, 
Choudhry S, et al: Polymorphisms in transforming growth factor-beta-related genes ALK1 and ENG are associated with sporadic brain arteriovenous malformations. Stroke 36:2278-2280, 2005

30. Pawlikowska L, Tran MN, Achrol AS, McCulloch CE, Ha C, Lind DL, et al: Polymorphisms in genes involved in inflammatory and angiogenic pathways and the risk of hemorrhagic presentation of brain arteriovenous malformations. Stroke 35:2294-2300, 2004

31. Phng LK, Potente M, Leslie JD, Babbage J, Nyqvist D, Lobov I, et al: Nrarp coordinates endothelial Notch and Wnt signaling to control vessel density in angiogenesis. Dev Cell 16:70-82, 2009

32. Simon M, Franke D, Ludwig M, Aliashkevich AF, Köster G, Oldenburg J, et al: Association of a polymorphism of the ACVRL1 gene with sporadic arteriovenous malformations of the central nervous system. J Neurosurg 104:945-949, 2006

33. Simon M, von der Brelie C, Schramm J: Vascular malformations and epilepsy, in Spetzler RF, Kalani MYS, Nakaji P (eds): Neurovascular Surgery, ed 2. New York: Thieme, 2015

34. Spetzler RF, Martin NA: A proposed grading system for arteriovenous malformations. J Neurosurg 65:476-483, 1986

35. Sturiale CL, Puca A, Sebastiani P, Gatto I, Albanese A, Di Rocco C, et al: Single nucleotide polymorphisms associated with sporadic brain arteriovenous malformations: where do we stand? Brain 136:665-681, 2013

36. Sun B, Qiu H, Zhao F, Qiao N, Fan W, Lu D, et al: The rs9509 polymorphism of MMP-9 is associated with risk of hemorrhage in brain arteriovenous malformations. J Clin Neurosci 19:1287-1290, 2012

37. Tien AC, Rajan A, Bellen HJ: A Notch updated. J Cell Biol 184:621-629, 2009

38. Untergasser A, Cutcutache I, Koressaar T, Ye J, Faircloth BC, Remm M, et al: Primer3 - new capabilities and interfaces. Nucleic Acids Res 40:e115, 2012

39. van Beijnum J, Lovelock CE, Cordonnier C, Rothwell PM, Klijn CJM, Al-Shahi Salman R: Outcome after spontaneous and arteriovenous malformation-related intracerebral haemorrhage: population-based studies. Brain 132:537-543, 2009

40. van Beijnum J, van der Worp HB, Buis DR, Al-Shahi Salman R, Kappelle LJ, Rinkel GJE, et al: Treatment of brain arteriovenous malformations: a systematic review and meta-analysis. JAMA 306:2011-2019, 2011

41. Weinsheimer S, Kim H, Pawlikowska L, Chen Y, Lawton MT, Sidney S, et al: EPHB4 gene polymorphisms and risk of intracranial hemorrhage in patients with brain arteriovenous malformations. Circ Cardiovasc Genet 2:476-482, 2009
42. Weinsheimer SM, Xu H, Achrol AS, Stamova B, McCulloch CE, Pawlikowska L, et al: Gene expression profiling of blood in brain arteriovenous malformation patients. Transl Stroke Res 2:575-587, 2011

43. Zhang R, Zhu W, Su H: Vascular integrity in the pathogenesis of brain arteriovenous malformation. Acta Neurochir Suppl 121:29-35, 2016

44. ZhuGe Q, Wu Z, Huang L, Zhao B, Zhong M, Zheng W, et al: Notch 4 is activated in endothelial and smooth muscle cells in human brain arteriovenous malformations. J Cell Mol Med 17:1458-1464, 2013

\section{Disclosures}

The authors report no conflict of interest concerning the materials or methods used in this study or the findings specified in this paper.

\section{Author Contributions}

Conception and design: Delev, Simon. Acquisition of data: Delev, Pavlova, Grote, Boström, Höllig. Analysis and interpretation of data: Delev, Pavlova, Simon. Drafting the article: Delev, Simon. Critically revising the article: Pavlova, Schramm, Oldenburg. Reviewed submitted version of manuscript: all authors. Approved the final version of the manuscript on behalf of all authors: Delev. Statistical analysis: Fimmers. Administrative/technical/material support: Delev, Pavlova, Grote, Höllig, Schramm, Oldenburg, Simon. Study supervision: Delev, Simon.

\section{Supplemental Information}

\section{Previous Presentations}

Portions of this work were presented in abstract form at the 64th Jahrestagung der deutschen Gesellschaft für Neurochirurgie (DGNC), Düsseldorf, Germany, May 26-29, 2013, and at the 14th European Congress of Neurosurgery (EANS 2012), Bratislava, Slovakia, October 24-27, 2012.

\section{Current Affiliations}

Dr. Delev: Department of Neurosurgery, University Medical Center Freiburg, Freiburg, Germany. Drs. Grote and Simon: Department of Neurosurgery, Evangelisches Krankenhaus Bielefeld, Germany.

\section{Correspondence}

Daniel Delev, Department of Neurosurgery, University of Freiburg, University Medical Center Freiburg, Breisacherstr. 64, 79106 Freiburg, Germany. email: delev.daniel@gmail.com. 